Media Informatika, Vol. 2, No. 2, Desember 2004, 13-21

ISSN: 0854-4743

\title{
LESSONS FROM E-GOVERNMENT INITIATIVES IN INDONESIA*
}

\author{
Fathul Wahid \\ Department of Informatics, Faculty of Industrial Engineering, \\ Islamic University of Indonesia \\ Jl. Kaliurang Km. 14 Yogyakarta 55501 \\ Telp. (0274) 895287 ext. 122, Faks. (0274) 895007 ext. 148 \\ E-mail: fathulwahid@fti.uii.ac.id
}

\begin{abstract}
E-government has accepted a considerable attention in last few years. Indonesia, like other counties, can take advantages of e-government initiatives, such as to improve transparency, control, and accountability towards implementation good governance. Initial observation through scanning of news on mass-media, similar phenomenon is also found in Indonesia. What are obstacles of e-government initiatives? Are there any best practices to eliminate the degree of the failure? Organizational and cultural inertia, financial constraints, and low ICT penetration, lack of ICT skills are of identified obstacles of egovernment implementation. Leadership with a clear vision, partnership with third parties, human resource and infrastructures improvement are some strategies can be offered to cope with the obstacles.
\end{abstract}

Keywords: e-Government, Indonesia

\section{INTRODUCTION}

E-government has accepted a considerable attention in last few years. Development of information and communication technology (ICT), especially the Internet, is considered as main driver behind e-government initiatives. ICT offers opportunity for government to better deliver its contents and services and interact with its many constituents; citizens, businesses, and other government partners (Chen, 2002). Indonesia, like other counties, can take advantages of e-government initiatives, such as (a) to support the government change towards a democratic governance practices; (b) to facilitate communication between central and local governments; (4) to improve transparency, control, and accountability towards implementation good corporate governance; and (5) to enable transformation towards information society era (Indrajit, 2002; Haryono and Widiwardono, 2004).

There is no single accepted definition of e-government in the literature. Broadly, e-government can be defined as the use all ICT platforms and applications by the public sector (UNDPEPA and ASPA, 2001). E-government can

* The main ideas of this paper have been presented in The 2004 Workshop of Norwegian Network on ICT and Development: e-Governance, e-Democracy and Development, Agder University College, Kristiansand, Norway, October 11 And 12 
be seen from various perspectives. Based on the relationship with other parties, some people classify e-government into three categories, government to citizen $(\mathrm{G} 2 \mathrm{C})$, government to business $(\mathrm{G} 2 \mathrm{~B})$, dan government to government $(\mathrm{G} 2 \mathrm{G})$ (e.g. Chen, 2002).

Previous research found that adoption of e-government increased in most countries but at the same time the rate of adoption varied from country to country. Generally, developing counties, includes Indonesia, is lagging in e-government adoption compared to developed countries. Based on Global e-Government Survey conducted in 2002, Indonesia was in 94th place from 197 surveyed countries (Darell, 2002). In their global survey, United Nations Division for Public Economics and Public Administration and American Society for Public Administration (UNDPEPA and ASPA, 2001) that developed e-government index to benchmark development of e-government put Indonesia as one of countries with minimum e-government capacity. The index is calculated by considering Web presence, telecommunications infrastructure, and human capital measures.

Finding from previous study revealed that only $15 \%$ of e-Government project in developing countries were successful. The rest were either total or partial failure (Heeks, 2003). According to him, design-reality gap in many aspects contributes to the failure. Through initial observation, similar phenomenon is also found in Indonesia.

This paper describes the development of and lessons learned of egovernment initiatives in Indonesia. Secondary data from various sources (e.g. magazines and new papers) is used as the basis of the paper.

\section{ICT AND E-GOVERNMENT DEVELOPMENT IN INDONESIA}

\subsection{ICT development in Indonesia}

The development of ICT is considered to be one of drivers of e-government initiatives (e.g. Letch, 2001). Previous study found that development ICT in terms of Internet adoption, phone line penetration, has significant association with egovernment adoption (Wahid, 2004). Hence, description of ICT development will give a better understanding of e-government initiatives in Indonesia.

The number of Internet hosts per 1000 people stand at 0.11 in Indonesia, compared to 13.45 in neighbouring Singapore (Wong, 2002) and 417 in the US (Roycroft and Anantho, 2003). The estimated annual expenditure per capita on services related to information and communication technology (ICT) is 9 USD in Indonesia and 2348 USD in Singapore. In spite of the relatively modest ICT expenditures and the low number of Internet hosts, use of the Internet spreads fast also in Indonesia. Using Internet service providers (ISPs) as a measure of Internet infrastructure development, we find that the number of licenses increased from one in 1994 to 180 by the end of 2003 (Purbo, 2002; APJII, 2004).

According to APJII (2004), the number of Internet subscribers increased from 134,000 in 1998 to 865,706 at the end of 2003. Interestingly, from 2001 to 2002 the number of home subscribers decreased and was compensated by an increasing number of corporate subscribers (from 10,539 in 2001 to 39,589 in 2002). The number of Internet users increased by more than $1400 \%$ during five years, from 
512,000 in 1998 to 8 million in 2003. APJII (2004) predicted that the number would be 12 million by the end of 2004. Considering a population of 216 million, the density of Internet users is still low, slightly more than $3.5 \%$ which is a bit more than the density of phone lines (3.1\%). The widespread public use of the Internet explains the faster growth of Internet users as compared to subscribers, and two thirds of Internet users in Indonesia today gain their access through Internet cafés. The development of Internet subscribers, users and ISP is depicted in Figure 1 and Figure 2 . Selected indicators of current status of information and communication technology (ICT) development is shown in Table 1.

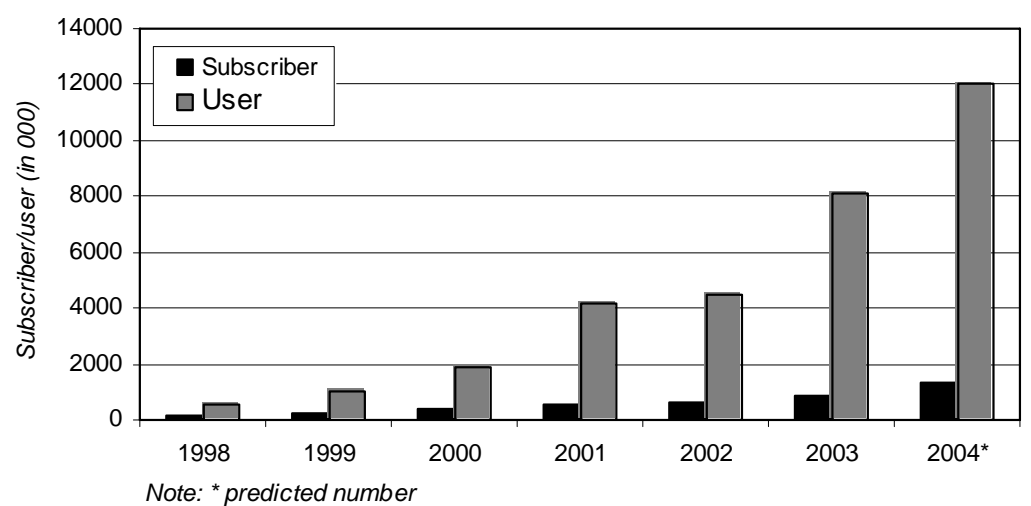

Figure 1. Developmnet of Internet subscribers and users

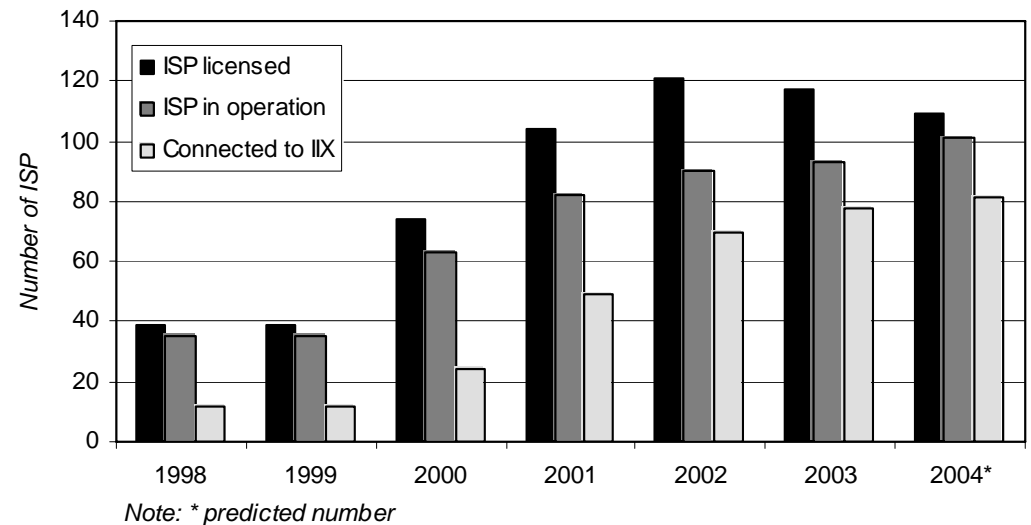

Figure 2. Developmnet of ISPs 
Table 1. Indonesia: selected indicators

\begin{tabular}{|l|c|}
\hline Population (millions) & 213.6 \\
\hline Poverty (\% of population below \$1 a day) & 12.9 \\
\hline Adult literacy rate (\% ages 15 and over) & 87.4 \\
\hline Urban population (\% of total population) & 42 \\
\hline GNI per capita (Atlas method, \$) & 680 \\
\hline GNI per capita (PPP, \$) & 2,940 \\
\hline Telephone mainlines per 1,000 people & 31 \\
\hline Telephone mainlines in largest city (per 1,000 people) & 232 \\
\hline Cost of local call (\$ per 3 minutes) & 0.02 \\
\hline Mobile phones (per 1,000 people) & 17 \\
\hline Daily newspapers (per 1,000 people) & 23 \\
\hline Radios (per 1,000 people) & 157 \\
\hline Television sets (per 1,000 people) & 149 \\
\hline PCs per 1,000 people & 9.9 \\
\hline PCs installed in education (thousands) & 58.5 \\
\hline Networked PCs (\%) & 37 \\
\hline Total ICT expenditure (\$, millions) & 3,540 \\
\hline ICT expenditure as \% of GDP & 2.2 \\
\hline ICT expenditure per capita (\$) & 16.6 \\
\hline Note: Statistics of 2000, source & http:/ WWW.WOrldban \\
\hline
\end{tabular}

Note: Statistics of 2000, source: http://www.worldbank.org

\section{2 e-Government initiatives in Indonesia}

In Indonesia, e-government has been a hot topic since the introduction of Presidential Instruction No. 3/2003 on July 2003, which contains national policy and strategy pertaining e-government development in Indonesia. However, before the introduction of the instruction, local governments have taken initiatives to develop e-government without any guideline from the central authority.

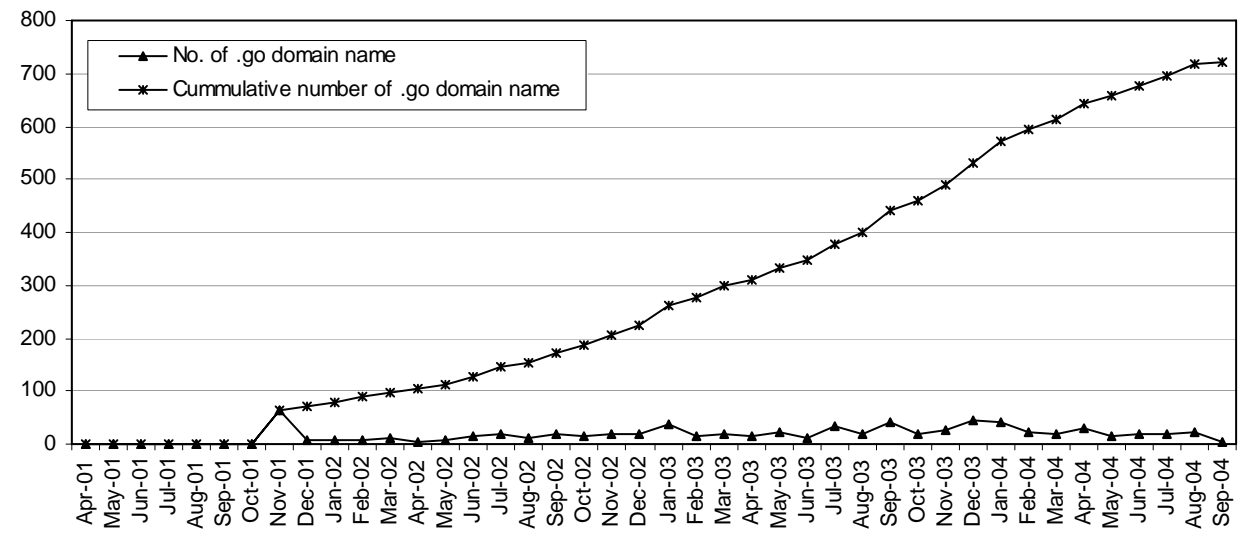

Figure 3. Statistics of go.id domain name

Source: http://www.idnic.net.id/

The first go.id domain name was registered in June 2001. Until July 2003, the number has increased significantly into 247 domain names which accounted for 
$34 \%$ of today's total go.id domain names (721). Figure 3 shows the statistics of go.id domain names.

However, we should note here that e-government is more than just a website on the Internet. The Internet is main interface of e-government application (i.e. front-office systems), but it should be supported by powerful information systems (i.e. back-office systems).

Regarding this back-office systems, in 1992, Department of Domestic Affairs has pioneered by developing so-called Communication Systems for Department of Domestic Affairs (Sistem Komunikasi Departemen Dalam Negeri - Siskomdagri) which also contained Management Information Systems for Local Government (Sistem Informasi Manajemen Pemerintah Daerah) (Rozy and Zoeltom, 2004b). In 1996, satellite-supported communication that utilized very small aperture terminal (VSAT) was used to integrate 345 nodes scattered geographically in central and local government offices. Ironically, the infrastructure was only used for voice communication. When economic crisis hit Indonesia in mid of 1998, the capacity of the network decreased to $30 \%$ and in 2001 only $10 \%$ of the capacity remained. In 2004, the network was revitalized in line with new strategies set up by the Indonesian government through implementation of National Information Systems (Sistem Informasi Nasional - Sisfonas) (Ahmadjayadi, 2004). Sisfonas is expected to become the main backbone of e-government in Indonesia, and Siskomdagri could be utilized as the second backbone.

Based on the data from Ministry of Communication and Information, it is shown that the adoption e-government by local government has been slow. The data shows that local governments, which include province government and city government ("kota" and "kabupaten") that have implemented e-government in various levels are accounted for $49.9 \%$ from the total number (Ahmadjayadi, 2003). The adoption in central/state government level indicates that $90 \%$ of the institutions have implemented e-government in various level functionalities (Ahmadjayadi, 2003).

Referring to stage model of e-government development as shown in Table 2, most e-government initiatives in Indonesia are on either emerging or enhanced presence. However, some has implemented interactive e-government. For instance, to increase transparency, Department of Housing and Region Infrastructure (www.kimpraswil.go.id) and Surabaya City (www.surabaya.go.id) have developed e-procurement system where public can access information of upcoming projects and take a part by giving bids. Transparancy is very important in Indonesia as one of countries where bribery is very common. According to Maarif, Ministry of Communication and Information, "Most e-government initiatives are still in web present stage, but some has reached transaction stage" (in Rozy and Zoeltom, 2004a) 
Table 2. The stages of e-Government

\begin{tabular}{|l|l|}
\hline Stage & Description \\
\hline Emerging & $\begin{array}{l}\text { A government web presence is established through a few } \\
\text { independent official sites. Information is limited, basic and } \\
\text { static. }\end{array}$ \\
\hline Enhanced & Content and information is updated with greater regularity. \\
\hline Interactive & $\begin{array}{l}\text { Users can download forms, contact officials, and make } \\
\text { appointments and requests. }\end{array}$ \\
\hline Transactional & $\begin{array}{l}\text { Users can actually pay for services or conduct financial } \\
\text { transactions online. }\end{array}$ \\
\hline Seamless & $\begin{array}{l}\text { Total integration of e-functions and services across } \\
\text { administrative and departmental boundaries. }\end{array}$ \\
\hline
\end{tabular}

Source: UNDPEPA and ASPA (2001, p. 10)

To foster the adoption of e-government in Indonesia, according to Presidential Instruction No. 3/2003, several strategies will be taken. They are (a) developing reliable, trust and affordable public services; (b) organization, management system and business process reform; (c) optimal use of ICT; (d) public-private partnership; (e) human resource development and increase society e-literacy; and (f) realistic and measurable implementation plan.

In connection to this, public pioneered by Warta Ekonomi magazine (www.wartaekonomi.com), every year since 2002, gives e-Government Award to government offices considered to be successful in implementing e-government. Though participation in such a public evaluation will give "political gain" to the awarded offices, still not more than $20 \%$ (120 offices) of the government offices indicate their willingness to participate (Arief and Nurdiana, 2004). Table 3 summarizes recipients of e-Government Award 2004.

Table 3. Recipients of e-Goverment Award 2004

\begin{tabular}{|l|l|l|}
\hline Category & Government office & Website address \\
\hline \multirow{4}{*}{ District/City } & Kebumen District & www.kebumen.go.id \\
\cline { 2 - 3 } & Bogor City & www.bogor.go.id \\
\cline { 2 - 3 } & Kutai Timur District & www.kutaitimur.go.id \\
\hline \multirow{4}{*}{ Province } & Yogyakarta Special Region & www.pemda-diy.go.id \\
\cline { 2 - 3 } & East Java & www.jatim.go.id \\
\cline { 2 - 3 } & Southern Sulawesi & www.sulut.go.id \\
\hline \multirow{5}{*}{$\begin{array}{l}\text { Nopartment } \\
\text { department }\end{array}$} & Department of Housing and Regional Infrastructure & www.kimpraswil.go.id \\
\cline { 2 - 3 } & Department of Domestics Affairs & www.depdagri.go.id \\
\cline { 2 - 3 } & Department of Agriculture & www.deptan.go.id \\
\cline { 2 - 3 } & Bank of Indonesia & www.bi.go.id \\
\cline { 2 - 3 } & Statistics Indonesia & www.pps.go.id \\
\cline { 2 - 3 } & National Library & \\
\hline
\end{tabular}

Source: Arief and Nurdiana (2004) 


\section{LESSONS LEARNED}

Organizational and cultural inertia, financial constraints, and low ICT penetration, lack of ICT skills are of identified obstacles of e-government implementation. However, some government offices have proven to eliminate degree of the obstacles with several initiatives. Several lessons can be learned from such initiatives.

\section{Lesson 1}

Leadership with a clear vision is a necessary in ensuring successful implementation of e-government. Change management to unfreeze organizational and cultural inertia can only be done with a strong leadership. The organizational and cultural changes often are more difficult than technological changes.

In a country with with high power distance culture (Hofstede, 1997), leader plays a very important role to decide "to go" or "not to go". I a cross-country study using data from 48 countries, Wahid (2004) found that this cultural diminsion had negative correlation with adoption of e-government. In general, the study (Wahid, 2004) found that culture had signifiacang effect on e-government adoption within a country.

Such a situation in Indonesia has been worsened by "short-cut" mentality among government officers. This mentality has been believed to be one of drivers behind massive corruption practices in Indonesia. Hence, paradigm in egovernment implementation should be altered from "project-oriented" (i.e. only to spend allocated budget) to "program-oriented" (i.e. to be based on consciousness to improve public services). Recipients of e-Government Award (see Table 3) have proven to have "program-oriented" paradigm and to show a good leadership with a strong commitment to utilize ICT in delivering better services to the public toward a clean and good governance practices.

\section{Lesson 2}

To cope with financial constraints, partnership with third parties through "mutualism symbiosis" and efficiency in budget allocation are among the strategies. For instance, District Kutai Timur have been developing partnership with local bank to manage payment. Yogyakarta nowadays is developing CDMA infrastructure to increase ICT accessibility and financially supported by a national bank in which all payment will go to the bank. From 2004, Indonesian taxpayers can pay land taxes through thousands ATMs throughout Indonesia owned by a national bank.

Lesson 3

As "the man behind the gun" is determining, ICT skills and knowledge among government employees should be improved through various programs. Lack of internal skilled-personnel may also be supplemented by involving external experts, such as ICT practitioners or academicians. For instance, many seminars have been held to socialize government's policy as regards e-government implementation and have been attended by many government employees. 
Trainings to improve government employees have been also conducted in many occasions by involving ICT practitioners or academicians.

Lesson 4

Programs to increase awareness and skills of public to use ICT should also be well-designed. Government offices cannot be a single fighter in this regards. Involvement of external actors, such as schools, universities, and non-government organizations are then essential. Several universities and NGOS had been participating in such a empowerement program to improve public skills in using ICT.

Lesson 5

Of the main question comes up regarding the development of e-government in Indonesia is: e-government for whom? Therefore, in national level as well as in local level, programs to increase capacity and accessibility of ICT infrastructure are important to broaden coverage of the services offered by e-government. Providing a low cost Internet access is an example. In this regards, the government should thank Internet cafe entrepreneurs to their initiative to provide such a low cost Internet access. Other similar initiatives can be done by the government. Without such efforts, only a handful of citizens who will get benefits from e-government and hence digital divide will widen.

\section{REFERENCES}

Ahmadjayadi, C. (2003). Peluang dan tantangan e-Government di era otonomi daerah. Paper presented at the Seminar Peluang dan Tantangan E-Government di Era Otonomi Daerah, Yogyakarta.

Ahmadjayadi, C. (2004). Siskomdagri dan Sisfonas. Warta Ekonomi, 15, 95-96.

APJII. (2004). Statistik APJII. Retrieved June 30, 2004, from http://www.apjii.or.id/ dokumentasi/statistik

Arief, M., and Nurdiana. (2004). Metodologi Menilai e-Government di Indonesia. Warta Ekonomi, 16, 86-87.

Chen, H. (2002). Digital Government: Technologies and Practices. Decision Support Systems, 34, 223-227.

Darell, M. W. (2002). Global E-Government 2002. Retrieved 15 Maret, 2002, from http: //www.insidepolitics.org/egovt02int

Haryono, T., and Widiwardono, Y. K. (2004). Current status and issues of eGovernment in Indonesia. Retrieved September 04, 2004, from http://www.aseansec.org/ 13802.htm

Heeks, R. (2003). Most eGovernment-for-Development Project Fail: How Can Risks be Reduced? (No. 14). Manchester: Institute for Development Policy and Management.

Hofstede, G. (1997). Cultures and Organizations: Software of the Mind. New York: McGraw-Hill. 
Indrajit, R. E. (2002). Electronic Government: Strategi Pembangunan dan Pengembangan Sistem Pelayanan Publik Berbasis Teknologi Digital. Yogyakarta: Andi.

Letch, N. (2001). The emerging e-Government research agenda: A report on recent international research. Paper presented at the 4th Western Australian Workshop on Information Systems Research (WAWISR 2001).

Purbo, O. W. (2002). Getting connected: The struggle to get Indonesia online. Inside Indonesia(72), 14-16.

Roycroft, T. R., and Anantho, S. (2003). Internet subscription in Africa: policy for a dual digital divide. Telecommunications Policy, 27(1-2), 61-74.

Rozy, F., and Zoeltom, A. (2004a). Menapak tahap transaksi, mana jaminan hukumnya? Warta Ekonomi, 16, 78-79.

Rozy, F., and Zoeltom, A. (2004b). Siskomdagri: bangkitnya (kembali) sang pelopor. Warta Ekonomi, 15, 90-92.

UNDPEPA, and ASPA. (2001). Benchmarking e-Government: A Global Perspective. USA: United Nations Division for Public Economics and Public Administration and American Society for Public Administration.

Wahid, F. (2004) "Apakah Budaya Berpengaruh Terhadap Adopsi e-Government?: Sebuah Studi Lintas-Negara", TEKNOIN, 8(4), 321-332.

Wong, P. K. (2002). ICT production and diffusion in Asia: Digital dividends or digital divide? Information Economics and Policy, 14(2), 167-187. 